\author{
Łukasz Kubiak \\ https://orcid.org/0000-0001-7535-7686 \\ Polska Akademia Nauk w Warszawie \\ Instytut Geografii i Przestrzennego Zagospodarowania \\ lukasz.kubiak@twarda.pan.pl
}

\title{
DYNAMIKA I SKUTKI SUBURBANIZACJI BYDGOSZCZY NA PRZYKŁADZIE GMINY NOWA WIEŚ WIELKA
}

\begin{abstract}
Abstrakt: W pracy przedstawiono dynamikę i skutki przeobrażenia struktury funkcjonalno-przestrzennej strefy podmiejskiej na przykładzie podbydgoskiej gminy Nowa Wieś Wielka, w której zachodzą zjawiska charakterystyczne dla niekontrolowanej suburbanizacji typu urban sprawl. Analizie zostały poddane intensywność oraz kierunki rozwoju osadnictwa o charakterze miejskim i sieci infrastruktury technicznej na tle zachodzących zmian ludnościowych. Ponadto ukazano politykę władz gminy wobec presji urbanizacyjnej oraz próby radzenia sobie z jej negatywnymi skutkami, w tym rodzącymi się konfliktami społeczno-przestrzennymi.

Słowa kluczowe: suburbanizacja, peryurbanizacja, urban sprawl, struktura funkcjonalno-przestrzenna, strefa podmiejska, Bydgoszcz, Nowa Wieś Wielka.
\end{abstract}

\section{DYNAMICS AND EFFECTS OF SUBURBANIZATION IN BYDGOSZCZ FUNCTIONAL URBAN AREA: THE CASE OF NOWA WIES WIELKA COMMUNE}

Abstract: The paper presents the dynamics and effects of the functional and spatial structure transformation of the suburban area into an example of the Nowa Wies Wielka commune near Bydgoszcz, in which uncontrolled urban sprawl occurs. The intensity and development of urban settlements and technical infrastructure networks have been analyzed against the background of population changes. In addition, there were presented the policy of the commune authorities towards urbanization pressure and attempts to cope with its negative effects, including emerging socio-spatial conflicts.

Keywords: suburbanization, periurbanization, urban sprawl, functional and spatial structure, suburban area, Bydgoszcz, Nowa Wies Wielka.

\section{WPROWADZENIE}

Coraz więcej osób chce posiadać własny dom z ogrodem na przedmieściach, pragnąc odnaleźć ciszę i spokój z dala od miejskiego zgiełku. W ten sposób ludzie dążą do poprawy warunków mieszkaniowych, ale także jest to forma manifestowania własnego awansu społecznego (Mantey, 2011; Zborowski, Raźniak, 2013). Dodatkowym atutem są niższe niż w miastach ceny działek budowlanych (Krajewska, 2011). Jednakże ten proces ma również drugie oblicze, bowiem wskutek przesiedlania się ludności na przedmieścia mają miejsce także negatywne procesy. Zabudowa mieszkaniowa wkracza na obszary, na których do tej pory dominowały inne funkcje (Lisowski, Grochowski, 2009). W Polsce proces ten zazwyczaj zachodzi w chaotyczny sposób, a taka sytuacja generuje liczne konflikty społeczno-przestrzenne (Kowalewski, Markowski, Śleszyński, 2018). Polskie miasta wojewódzkie znajdują się aktualnie w fazie suburbanizacji i do takich należy także Bydgoszcz (Kowalczyk, 2002). Procesy osadnicze zachodzące $\mathrm{w}$ okolicach tego miasta występują z opóźnieniem czasowym oraz na mniejszą skalę niż w największych polskich metropoliach (Śleszyński, 2013). Dzięki temu istnieje możliwość czerpania z doświadczeń innych, aby zapobiegać negatywnym zjawiskom związanym z niekontrolowaną suburbanizacją. Niestety, wnioski nie są wyciągane, a błędy nadal powielane. Intensywny rozwój zabudowy mieszkaniowej jest szczególnie widoczny w okalającym miasto powiecie bydgoskim. Suburbanizacja jest złożonym procesem, który można rozpatrywać w wielu wymiarach, co powoduje, że w jednym opracowaniu nie można szczegółowo opisać wszystkich jej aspektów.

Celem autora niniejszej pracy jest pokazanie negatywnej roli niekontrolowanej suburbanizacji typu 
urban sprawl (Oueslati, Alvanides, Garrod, 2015). Tego rodzaju spontaniczny i chaotyczny rozwój strefy podmiejskiej generuje koszty w trzech podstawowych aspektach: ekonomicznym, środowiskowym i społecznym. Znane są mechanizmy kontrolne ograniczające występowanie niekontrolowanej suburbanizacji, lecz w obliczu presji społecznej władze lokalne $\mathrm{z}$ nich nie korzystają, a regulacje ustawowe nie zapobiegają powstawaniu chaosu przestrzennego (Kowalewski, Markowski, Śleszyński, 2018).

Przeprowadzone badanie polegało na analizie skutków wewnętrznych zmian funkcjonalno-przestrzennych oraz dynamiki procesu urban sprawl, położonej w powiecie bydgoskim gminy Nowa Wieś Wielka. Ta gmina została wybrana ze względu na reprezentatywność zachodzących procesów osadniczych dla gmin powiatu bydgoskiego. W gminie Nowa Wieś Wielka występują znaczne opóźnienia $\mathrm{w}$ rozwoju infrastruktury towarzyszącej w stosun$\mathrm{ku}$ do rozwoju mieszkalnictwa. Ponadto nowa zabudowa zajmuje coraz większe tereny nieprzystosowane do rozwoju mieszkalnictwa, a w "Studium uwarunkowań i kierunków zagospodarowania przestrzennego gminy Nowa Wieś Wielka" z 2006 r. wyznaczono zbyt wiele terenów pod rozwój funkcji mieszkaniowej, które i tak nie ograniczają zabudowy obszarów poddanych presji urbanizacyjnej.

W celu przeprowadzenia badania zostały sformułowane następujące pytania badawcze:

1. W jakim stopniu tereny, na których występuje funkcja mieszkaniowa w gminie Nowa Wieś Wielka, są wyposażone w infrastrukturę techniczną?

2. Jakie konflikty powstają wskutek nieskoordynowanej zmiany struktury funkcjonalno-przestrzennej w gminie Nowa Wieś Wielka?

3. Jakie działania podejmują władze gminy Nowa Wieś Wielka w obliczu presji urbanizacyjnej?

\section{METODA BADAŃ}

W analizie wykorzystano dane udostępnione w Banku Danych Lokalnych GUS, a także dane i informacje pozyskane w Urzędzie Gminy w Nowej Wsi Wielkiej, takie jak: liczba ludności według miejscowości w podziale na poszczególne lata (1980-2013), dane dotyczące gminnej sieci wodociągowej i kanalizacyjnej oraz na temat występujących na terenie gminy procesów społecznych, gospodarczych i środowiskowych. Skutki suburbanizacji gminy Nowa
Wieś Wielka zostały przedstawione na tle zmian ludnościowych oraz dynamiki rozwoju sieci wodociągowej i kanalizacyjnej. Zastosowano m.in. analizę porównawczą szeregów czasowych. Na przykładzie analizowanej podmiejskiej gminy zaprezentowano także przykładowe konflikty społeczno-przestrzenne oraz politykę władz gminy, poddanej silnej presji urbanizacyjnej. $W$ tym celu zastosowano analizę dostępnych źródel, w tym stron internetowych, lokalnej prasy („Gazeta Regionalna. Powiat”) oraz "Studium uwarunkowań i kierunków zagospodarowania przestrzennego gminy Nowa Wieś Wielka" (2006).

\section{STUDIUM PRZYPADKU - GMINA NOWA WIEŚ WIELKA}

\subsection{CHARAKTERYSTYKA OBSZARU BADAŃ}

Przedmiotem badania jest dynamika i skutki suburbanizacji w gminie Nowa Wieś Wielka, która leży w województwie kujawsko-pomorskim i jest jedną z ośmiu gmin wchodzących w skład powiatu bydgoskiego.

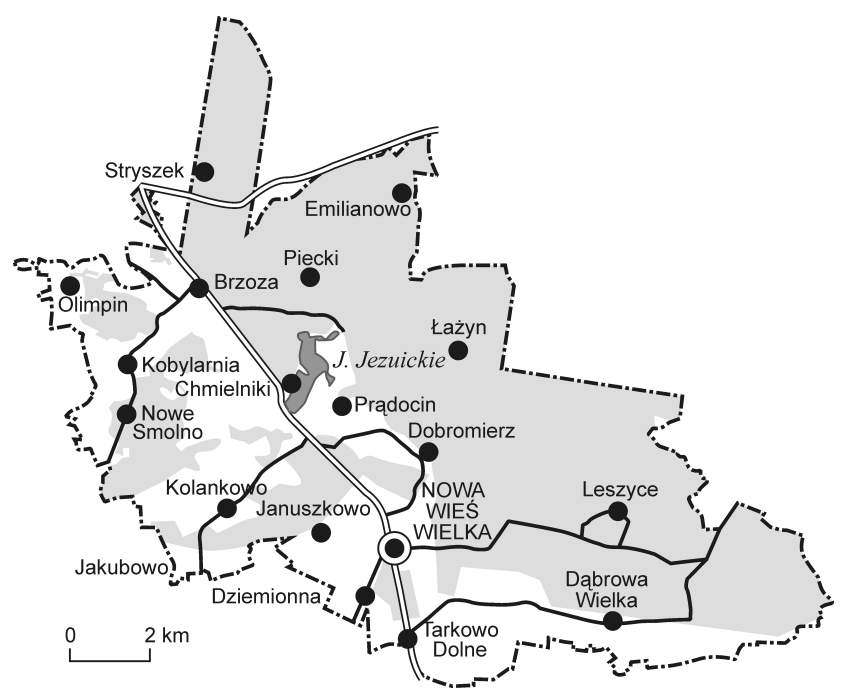

Rys. 1. Gmina Nowa Wieś Wielka w województwie kujawsko-pomorskim

Źródło: opracowanie A. Wosiak na podstawie www.maps.google.pl

Analizowana jednostka samorządu terytorialnego jest gminą wiejską, w której znajduje się 18 miejscowości (rys. 1). Samodzielne sołectwa tworzy 14 $\mathrm{z}$ nich. Wyjątkiem jest sołectwo Brzoza, które składa się dodatkowo z miejscowości: Chmielniki, Piecki i Emilianowo. Gmina graniczy bezpośrednio z Byd- 
goszczą, jednak jest od niej morfologicznie oddzielona szerokim na $10 \mathrm{~km}$ pasem lasu $\mathrm{w}$ postaci Puszczy Bydgoskiej. Wskutek tego około 60\% jej powierzchni stanowią bardzo ekstensywnie zaludnione obszary leśne, położone $\mathrm{w}$ większości w pólnocnej i zachodniej części gminy. Z kolei w jej centralnej części znajduje się Jezioro Jezuickie, które $\mathrm{w}$ sezonie letnim jest jednym z głównych kąpielisk dla mieszkańców aglomeracji bydgoskiej.

\subsection{PROCESY OSADNICZE WOKÓt BYDGOSZCZY}

Pierwszymi kierunkami intensywnego rozwoju funkcji mieszkaniowej, związanej z przeprowadzaniem się bydgoszczan na przedmieścia, były gminy Osielsko i Białe Błota (rys. 2). Wynikało to ze stosunkowo lepszej dostępności komunikacyjnej tych jednostek do Bydgoszczy w porównaniu z pozostałymi gminami obecnego powiatu bydgoskiego. W latach 90 . $X X$ w. przeprowadzała się do nich przede wszystkim najzamożniejsza część ludności. Wtedy nastąpił chociażby rozwój Niemcza (gm. Osielsko), dla którego obecnie charakterystyczna jest zabudowa willowa (Szymańska, Hołowiecka, 2000). Wskutek nasycenia zabudową i wzrostu cen ziemi $w$ wymienionych gminach $\mathrm{w}$ dalszej kolejności zyskały na atrakcyjności gminy Solec Kujawski i Nowa Wieś Wielka (Głębocki, Perdał, 2013; Gotowski, 2007). $\mathrm{W}$ ostatnich latach natomiast mamy do czynienia $\mathrm{z}$ intensywnym rozwojem funkcji mieszkaniowej także $\mathrm{w}$ pozostałych gminach powiatu bydgoskiego, na obszarach coraz bardziej oddalonych od centrum Bydgoszczy (Falkowski, Ilieva, Józefowicz, Rabant, 2015; Maik, 2010).

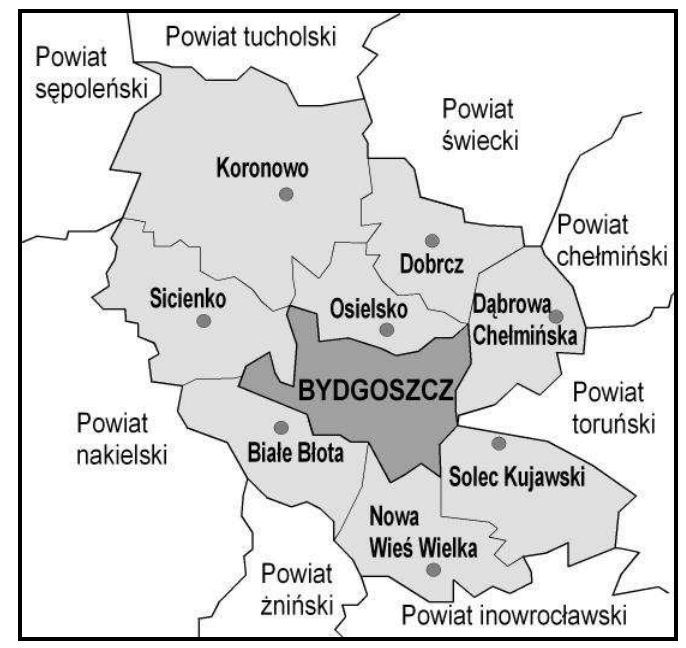

Rys. 2. Gminy powiatu bydgoskiego Źródło: www.powiatbydgoski.pl
W ostatnim czasie obserwuje się regularny wzrost liczby ludności $\mathrm{w}$ powiecie bydgoskim. W latach 2005-2012 rejestrowana liczba ludności zwiększyła się o 14,5 tys. (15,3\%). Zdecydowana większość nowych mieszkańców zasiliła ludność na obszarach administracyjnie wiejskich (13,3 tys.), co stanowi 91,5\% ogólu przyrostu ludności. Wskutek tego odsetek ludności administracyjnie miejskiej, czyli mieszkańców Solca Kujawskiego i Koronowa, zmniejszył się o 2,5 pkt. procentowego do poziomu $24,7 \%$. Oznacza to, że na terenach wiejskich ma miejsce zdecydowanie większa presja urbanizacyjna.

\subsection{ROZWÓJ GMINY NOWA WIEŚ WIELKA}

\subsubsection{LICZBA LUDNOŚCI GMINY A SIEĆ OSADNICZA}

Apogeum przyrostu liczby ludności gminy Nowa Wieś Wielka przypadło na lata 2001-2011, kiedy prawie każdego roku (z wyjątkiem 2002, 2005 oraz 2010) przybywało w niej ponad 150 nowych mieszkańców (rys. 3). Z powodu jej położenia w bezpośrednim sąsiedztwie Bydgoszczy, najwięcej z nich przenosiło się właśnie z tego miasta (rys. 4).

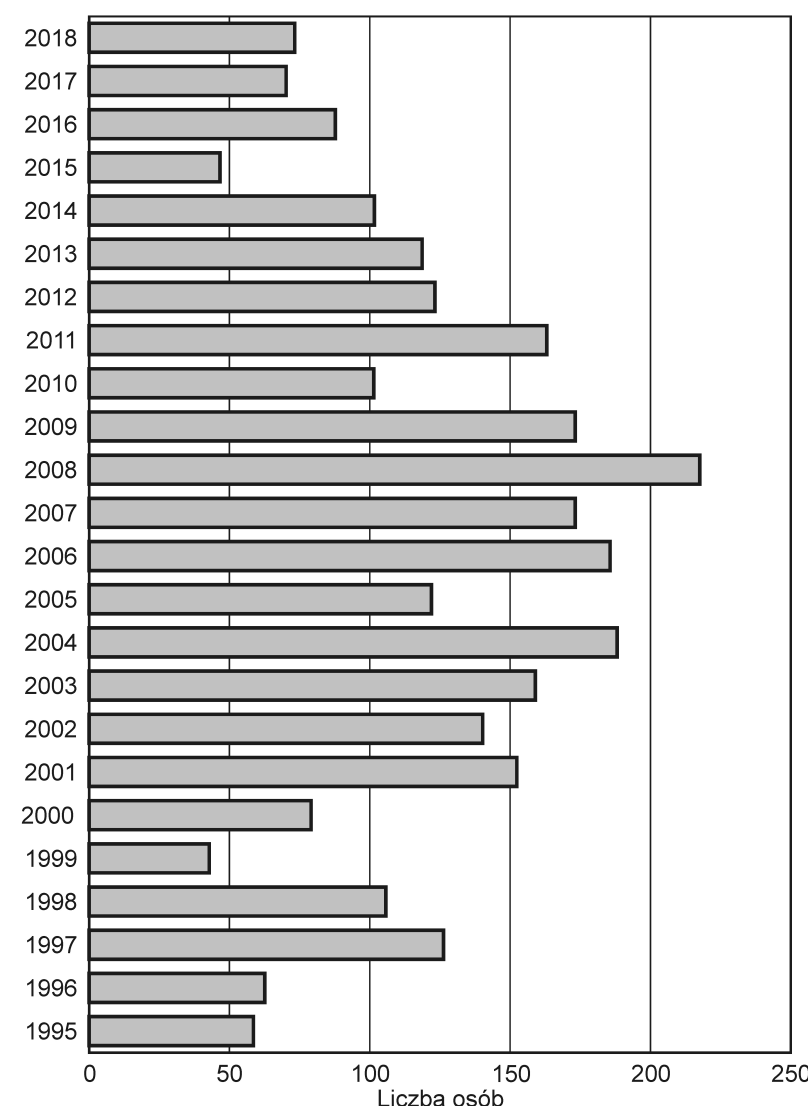

Rys. 3. Saldo migracji w gminie Nowa Wieś Wielka w latach 1995-2018

Źródło: opracowanie własne na podstawie danych z Banku Danych Lokalnych 


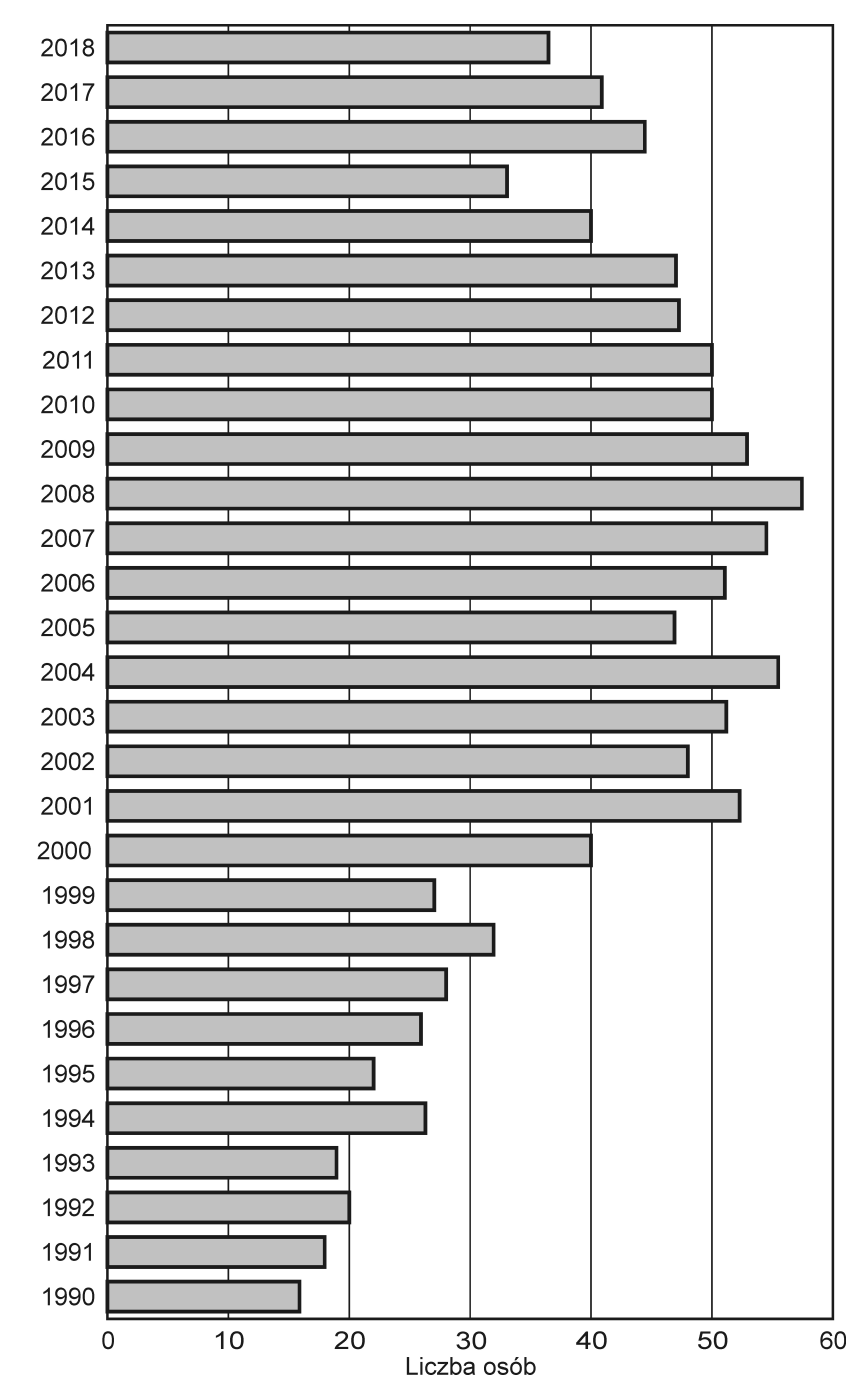

Rys. 4. Liczba przemeldowań z Bydgoszczy do gminy Nowa Wieś Wielka w latach 1990-2018 Źródło: opracowanie własne na podstawie danych z Banku Danych Lokalnych

Skutkiem położenia gminy na skraju Puszczy Bydgoskiej jest bardzo nierównomierne rozmieszczenie jej ludności. Na terenie sołectwa Leszyce i zachodniej części sołectwa Brzoza (obszar zalesiony z miejscowościami Piecki i Emilianowo), czyli 53\% powierzchni gminy, zamieszkuje zaledwie 108 osób (1,14\% ogółu ludności), a gęstość zaludnienia wynosi 1,2 osoba $/ \mathrm{km}^{2}$. Liczba ludności poszczególnych sołectw waha się od 40 osób w Kolankowie do $3214 \mathrm{w}$ solectwie Brzoza (stan na 7.06.2013 r.). W "Studium uwarunkowań i kierunków zagospodarowania przestrzennego gminy Nowa Wieś Wielka" z 2006 r. zaznacza się, że atutem struktury osadniczej gminy jest wysoki stopień jej koncentracji $\mathrm{w}$ dwóch głównych zespołach miejscowości Brzoza - Olimpin oraz Nowa Wieś Wielka - Dziemionna. W 2005 r. zamieszkiwało je 5811 osób z 7874 mieszkańców gminy (73,8\% ogółu ludności).
Im większy stopień koncentracji ludności, tym mniejsze koszty doprowadzenia sieci infrastruktury technicznej. W latach 2005-2013 liczba ludności tych miejscowości wzrosła o 997 osób - do poziomu 6808, jednak liczba mieszkańców całej gminy zwiększyła się do 9465 osób, co spowodowało spadek udziału ludności głównych miejscowości o 2 pkt. procentowe - do poziomu $72 \%$. W tym samym okresie liczba ludności peryferyjnych miejscowości gminy wzrosła z 2063 do 2657 (tab. 1).

Największe przyrosty liczby ludności w latach 1990-2013 zostały zanotowane w dwóch głównych ośrodkach (rys. 5): Brzoza - Olimpin (1777 osób), Nowa Wieś Wielka - Dziemionna (1255). Jedynie one mają wyraźnie wykształcone wielofunkcyjne centra. W Brzozie i Nowej Wsi Wielkiej znajdują się instytucje, których nie ma w pozostałych miejscowościach, takie jak: szkoła podstawowa, parafialny kościół katolicki, sklepy samoobsługowe, bankomaty, klub piłkarski zrzeszony w Polskim Związku Piłki Nożnej, przychodnia, apteki, Ochotnicza Straż Pożarna, urząd pocztowy. Takie zagospodarowanie wsi sprawia, że funkcjonalnie gmina jest układem bipolarnym.

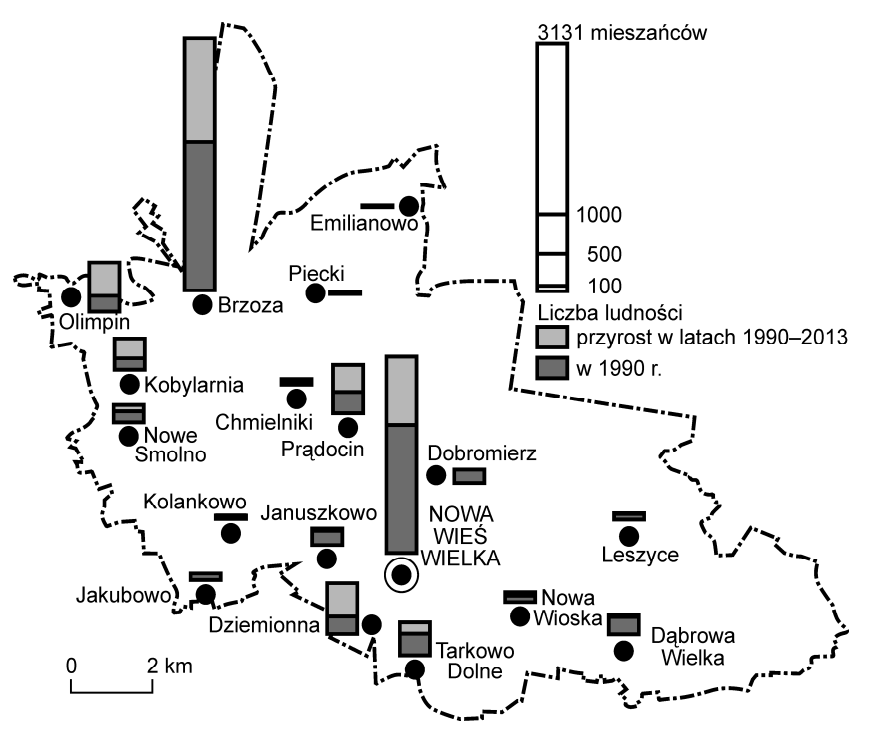

Rys. 5. Przyrost liczby ludności w poszczególnych miejscowościach gminy Nowa Wieś Wielka w latach 1990-2013a (a liczba ludności na 7.06.2013 r.)

Źródło: opracowanie własne na podstawie danych z Urzędu Gminy Nowa Wieś Wielka

W niniejszym artykule Brzoza jest często rozpatrywana łącznie z Olimpinem, gdyż funkcjonalnie jest to jeden organizm. Osiedle to jest silnie funkcjonalnie powiązane z Brzozą, w której jego mieszkańcy korzystają z dostępnych tam usług. Jest to jednostronne ciążenie, ponieważ w osiedlu Olimpin 
Tab. 1. Liczba ludności w miejscowościach gminy Nowa Wieś Wielka w latach 1980-2013

\begin{tabular}{|c|c|c|c|c|c|c|c|c|}
\hline \multirow{2}{*}{ Miejscowość } & \multicolumn{8}{|c|}{ Liczba ludności } \\
\hline & $1980^{a}$ & $1985^{a}$ & 1990 & 1995 & 2000 & 2005 & 2010 & $2013^{b}$ \\
\hline Brzoza & 1014 & 1393 & 1840 & 2147 & 2389 & 2743 & 3005 & 3131 \\
\hline Nowa Wieś Wielka & 794 & 1074 & 1600 & 1940 & 2084 & 2202 & 2367 & 2449 \\
\hline Dziemionna & 139 & 179 & 217 & 284 & 394 & 458 & 577 & 623 \\
\hline Olimpin & 72 & 93 & 119 & 146 & 240 & 404 & 559 & 605 \\
\hline Prądocin & 180 & 220 & 272 & 313 & 341 & 384 & 499 & 602 \\
\hline Tarkowo Dolne & 142 & 205 & 284 & 305 & 307 & 328 & 378 & 420 \\
\hline Kobylarnia & 92 & 113 & 142 & 158 & 159 & 209 & 332 & 395 \\
\hline Dąbrowa Wielka & - & - & 227 & 237 & 235 & 230 & 214 & 244 \\
\hline Nowe Smolno & - & - & 135 & 168 & 182 & 190 & 211 & 226 \\
\hline Januszkowo & - & - & 179 & 187 & 171 & 190 & 196 & 199 \\
\hline Dobromierz & - & - & 169 & 165 & 156 & 165 & 161 & 167 \\
\hline Nowa Wioska & - & - & 91 & 107 & 102 & 97 & 104 & 123 \\
\hline Leszyce & - & - & 75 & 78 & 80 & 72 & 78 & 82 \\
\hline Jakubowo & - & - & 78 & 68 & 65 & 73 & 79 & 76 \\
\hline Chmielniki & - & - & 40 & 44 & 52 & 49 & 54 & 57 \\
\hline Kolankowo & - & - & 34 & 34 & 22 & 22 & 29 & 40 \\
\hline Piecki & - & - & 19 & 33 & 38 & 27 & 24 & 17 \\
\hline Emilianowo & - & - & 9 & 9 & 10 & 11 & 9 & 9 \\
\hline Razem & 3228 & 4279 & 5530 & 6423 & 7027 & 7854 & 8876 & 9465 \\
\hline
\end{tabular}

Objaśnienia: a liczba ludności wybranych miejscowości, b liczba ludności na dzień 7.06.2013 r.

Źródło: opracowanie własne na podstawie danych z Urzędu Gminy Nowa Wieś Wielka.

Tab. 2. Udział przyrostu liczby mieszkańców gminy według poszczególnych miejscowości w latach 1990-2013

\begin{tabular}{|c|c|c|c|c|c|c|}
\hline \multirow[t]{2}{*}{ Miejscowość } & \multicolumn{5}{|c|}{$\begin{array}{l}\text { Przyrosty ludności w odsetkach w poszczególnych miejscowościach } \\
\text { w odniesieniu do ogółu ludności gminy (kolumna pionowo = 100\%) }\end{array}$} & \multirow[t]{2}{*}{ 1990-2013 } \\
\hline & 1990-1995 & $1995-2000$ & 2000-2005 & $2005-2010$ & $2010-2013^{a}$ & \\
\hline Brzoza & 34,4 & 40,1 & 42,8 & 25,6 & 21,4 & 32,8 \\
\hline Nowa Wieś Wielka & 38,1 & 23,8 & 14,3 & 16,1 & 13,9 & 21,6 \\
\hline Dziemionna & 7,5 & 18,2 & 7,7 & 11,6 & 7,8 & 10,3 \\
\hline Olimpin & 3,0 & 15,6 & 19,8 & 15,2 & 7,8 & 12,4 \\
\hline Prądocin & 4,6 & 4,6 & 5,2 & 11,3 & 17,5 & 8,4 \\
\hline Tarkowo Dolne & 2,4 & 0,3 & 2,5 & 4,9 & 7,1 & 3,5 \\
\hline Kobylarnia & 1,8 & 0,2 & 6,0 & 12,0 & 10,7 & 6,4 \\
\hline Dąbrowa Wielka & 1,1 & $-0,3$ & $-0,6$ & $-1,6$ & 5,1 & 0,4 \\
\hline Nowe Smolno & 3,7 & 2,3 & 1,0 & 2,1 & 2,5 & 2,3 \\
\hline Januszkowo & 0,9 & $-2,6$ & 2,3 & 0,6 & 0,5 & 0,5 \\
\hline Dobromierz & $-0,4$ & $-1,5$ & 1,1 & $-0,4$ & 1,0 & $-0,1$ \\
\hline Nowa Wioska & 1,8 & $-0,8$ & $-0,6$ & 0,7 & 3,2 & 0,8 \\
\hline Leszyce & 0,3 & 0,3 & $-1,0$ & 0,6 & 0,7 & 0,2 \\
\hline Jakubowo & $-1,1$ & $-0,5$ & 1,0 & 0,6 & $-0,5$ & $-0,1$ \\
\hline Chmielniki & 0,4 & 1,3 & $-0,4$ & 0,5 & 0,5 & 0,4 \\
\hline Kolankowo & 0,0 & $-2,0$ & 0,0 & 0,7 & 1,9 & 0,2 \\
\hline Piecki & 1,6 & 0,8 & $-1,3$ & $-0,3$ & $-1,2$ & $-0,1$ \\
\hline Emilianowo & 0,0 & 0,2 & 0,1 & $-0,2$ & 0,0 & 0,0 \\
\hline
\end{tabular}

Objaśnienia: a do 7.06.2013 r.

Źródło: opracowanie własne na podstawie danych z Urzędu Gminy Nowa Wieś Wielka.

praktycznie występuje tylko funkcja mieszkaniowa. Do końca lat 70. XX w., czyli do czasu wybudowania w Brzozie nowego gmachu szkolnego, w Olimpinie znajdowała się szkoła podstawowa, w której mieściły się oddziały klas V-VIII. Korzystały z niej także dzieci z Brzozy, gdzie wówczas odbywały się zajęcia dla klas I-IV. Między obiema miejscowo- ściami występują też silne powiązania przestrzenne, pomimo że położone są po dwóch stronach doliny Noteci. Najbliższe budynki użyteczności publicznej zlokalizowane w Brzozie znajdują się $300 \mathrm{~m}$ od najbliższych domów w Olimpinie. To zdecydowanie bliżej niż peryferyjne części Brzozy, takie jak osiedle Ptasie czy Stryszek. 
Drugi tak silnie przestrzennie połączony zespół miejscowości stanowi Nowa Wieś Wielka i Dziemionna. W tym przypadku nie ma nawet czytelnej w przestrzeni granicy geograficznej, a zabudowania obu miejscowości bezpośrednio ze sobą graniczą. $\mathrm{W}$ związku z intensywnym rozwojem zabudowy silna amalgamacja przestrzenna zachodzi również w przypadku Brzozy i Przyłęk, które leżą już w innej gminie (Białe Błota). Na odcinku $700 \mathrm{~m}$ granica gminy ciągnie się wzdłuż ul. Powstańców Wielkopolskich (w Przyłękach ta ulica nosi nazwę Zabytkowa). Nie widać żadnych granic geograficznych ani nie występuje luka $\mathrm{w}$ zabudowie, natomiast widoczne są braki infrastrukturalne. Na granicznym odcinku nie ma oświetlenia ulicznego i chodnika, gdyż obie gminy jak dotąd nie dogadały się w sprawie partycypacji w kosztach budowy i późniejszego utrzymania powstałej tam infrastruktury. Odbija się to negatywnie na bezpieczeństwie $w$ tym rejonie, gdyż jest to jedyna utwardzona droga łącząca Przylęki z Brzozą. W obu miejscowościach systematycznie przybywa mieszkańców, co powoduje intensyfikację ruchu kołowego i pieszego. Ponadto ul. Powstańców Wielkopolskich służy mieszkańcom Przyłęk jako dojazd do drogi wojewódzkiej nr 254. Mieszkańcy Przyłęk, podobnie jak mieszkańcy Olimpina, korzystają z usług zlokalizowanych w Brzozie ze względu na ich niedobór w swojej miejscowości.

Na kolejnych pozycjach pod względem skumulowanego przyrostu liczby ludności znajdują się miejscowości Prądocin (330) i Kobylarnia (253). Szczególnie duży wzrost liczby ludności notowany jest tam w ostatnich ośmiu latach - 218 osób w Prądocinie oraz 186 w Kobylarni. Są to ośrodki, do których trafiła druga fala suburbanizacji (tab. 2). Ich mieszkańcy korzystają także z podstawowych usług w Brzozie i Nowej Wsi Wielkiej.

Prądocin znajduje się przy drodze krajowej nr 25, mniej więcej w połowie drogi między Brzozą a Nową Wsią Wielką. To jedyna miejscowość w gminie, która nie wykazuje wyraźnego ciążenia do żadnej z dwóch głównych miejscowości. Prądocin jest położony na zachodnim brzegu Jeziora Jezuickiego, dlatego dominuje tu funkcja rekreacyjna i znajduje się w nim sześć Rodzinnych Ogródków Działkowych, w których jest około 830 domów. Oznacza to, że w okresie wakacyjnym faktyczna liczba rezydentów może nawet kilkakrotnie przekraczać liczbę mieszkańców tej miejscowości (602).

Ogródki działkowe w Prądocinie są główną przyczyną eutrofizacji Jeziora Jezuickiego.

\subsubsection{ROZWÓJ SIECI KANALIZACYJNEJ I WODOCIĄGOWEJ}

Budowę sieci kanalizacyjnej w Nowej Wsi Wielkiej rozpoczęto przed zakończeniem prac związanych z budową samego obiektu oczyszczalni ścieków w 1993 r. Na pierwszym etapie wybudowano 180 przyłączy, co pozwoliło na przeprowadzenie rozruchu technologicznego obiektu. W 1994 r. liczba przyłączy wzrosła do 410, a długość sieci kanalizacyjnej wyniosła 12,2 km. Następnym etapem rozbudowy kanalizacji było otwarcie nowej oczyszczalni ścieków w Brzozie. Wiązało się to ze skanalizowaniem tej miejscowości i dalszym wzrostem liczby połączeń kanalizacyjnych w gminie do 740 (1997 r.), a następnie do 835 (1998 r.). Długość kanalizacji powiększyła się do 20,4 km w $1997 \mathrm{r}$. i 22,7 km w roku 1998. Następne inwestycje przeprowadzone w Brzozie, Olimpinie i Dziemionnie spowodowały, że nastąpił wzrost długość sieci do $39 \mathrm{~km}$, a liczba przyłączy do 1460 w 2012 r. (rys. 6).

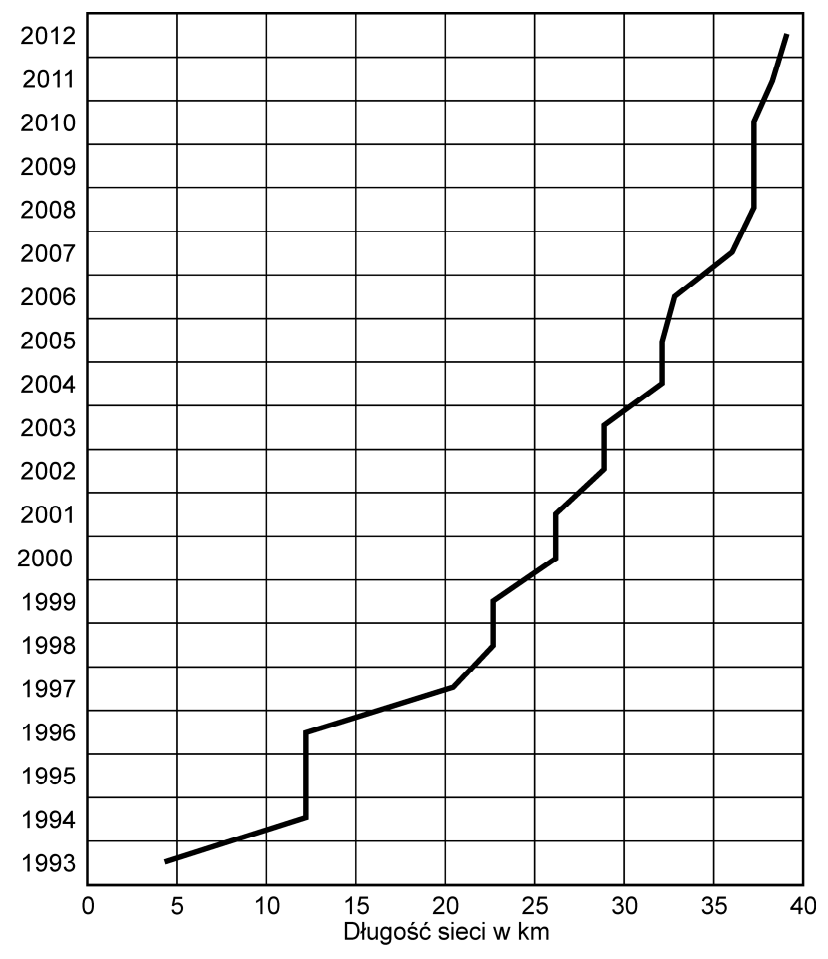

Rys. 6. Rozrost sieci kanalizacyjnej w gminie Nowa Wieś Wielka w latach 1993-2012

Źródło: opracowanie własne na podstawie danych udostępnionych przez Zakład Gospodarki Komunalnej w Nowej Wsi Wielkiej

W omawianej gminie znajdują się dwie duże wsie posiadające sieć wodociągową. Są to Nowa Wieś Wielka i Brzoza. Według wskaźnika „zwodociągowania" gminy na 2008 r. sieć ta zaopatruje w wodę około 82\% mieszkańców gminy. W 2012 r. długość 
wodociągu osiągnęła 98,6 km, przy 1812 przyłączach (rys. 7) i nadal jest rozbudowywana. Planowane inwestycje powinny umożliwić doprowadzenie wody do $89 \%$ mieszkań, z nowo budowanymi włącznie. Rozbudowa była możliwa po uruchomieniu w 2008 r. stacji uzdatniania wody w Prądocinie, której celem miało być wspomaganie pracy stacji Nowa Wieś Wielka i Brzoza. Mogła ona również zasilać $\mathrm{w}$ wodę nowe tereny, w tym działki rekreacyjne czy obszary przeznaczone pod zabudowę mieszkalną otaczającą Jezioro Jezuickie. Na tle pozostałych gmin powiatu bydgoskiego gmina Nowa Wieś Wielka charakteryzuje się najmniejszą dostępnością mieszkańców do sieci wodociągowej.

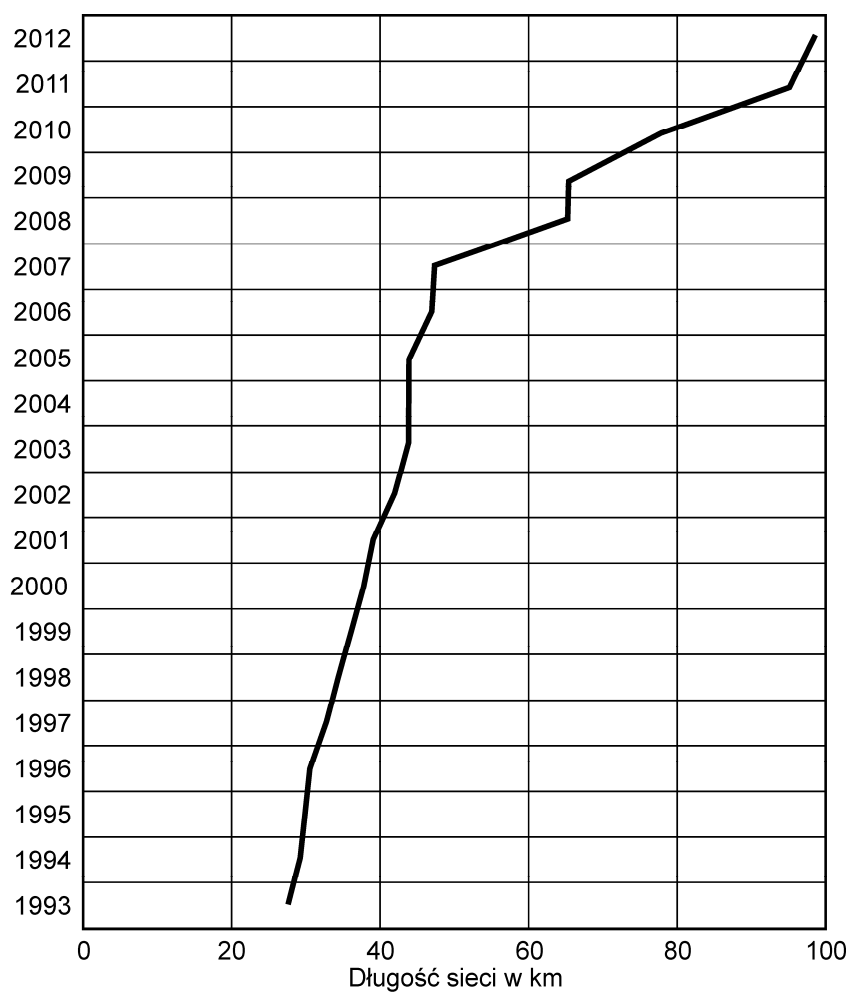

Rys. 7. Rozrost sieci wodociągowej w gminie Nowa Wieś Wielka w latach 1993-2012

Źródło: opracowane własne na podstawie danych z Zakładu Gospodarki Komunalnej w Nowej Wsi Wielkiej

\subsection{PRZYKŁADY KONFLIKTÓW SPOŁECZNO-PRZESTRZENNYCH}

Chaotyczna urbanizacja generuje wiele konfliktów społeczno-przestrzennych. Powstające napięcia przyczyniają się do spadku jakości życia, nieefektywności lokalnych układów osadniczych i degradacji środowiska (Jaroszewska-Brudnicka, 2009; Kajdanek, 2012; Kowalewski, Markowski, Śleszyński, 2018; Mantey, 2011). Poniżej zaprezentowano trzy konflikty, które wystąpiły na terenie badanej gminy Nowa Wieś Wielka.

\subsubsection{EUTROFIZACJA JEZIORA JEZUICKIEGO}

Jeszcze pod koniec lat 70. XX w. Jezioro Jezuickie było jeziorem oligotroficznym. Od tego czasu sytuacja zaczęła się zmieniać. W Chmielnikach i Pieckach zagospodarowano plaże, przy których wybudowano ośrodki wypoczynkowe. Plaże stały się miejscem wypoczynku wielu bydgoszczan w upalne dni. Oprócz tego na południowym i zachodnim brzegu jeziora, w miejscowości Prądocin, zaczęto tworzyć ogródki działkowe. W krótkim czasie powstało ponad 800 działek $\mathrm{z}$ domkami letniskowymi. Pojawił się problem produkowanych tam ścieków, gdyż obszar nie był skanalizowany. Ścieki odprowadzano do szamb w bezpośrednim sąsiedztwie jeziora, powodując ich przenikanie do jeziora i dostarczanie do niego substancji organicznych. Glony zaczęły zakwitać i woda zielenić się, co jeszcze bardziej spotęgowało antropopresję i proces zarastania jeziora. Stężenie substancji organicznej $\mathrm{w}$ wodzie osiągało poziomy niebezpieczne dla zdrowia człowieka, gdyż jezioro ma zaledwie $0,005063 \mathrm{~km}^{3}$ objętości („,Studium uwarunkowań i kierunków zagospodarowania przestrzennego gminy Nowa Wieś Wielka", 2005). Sanepid zaczął czasowo zamykać kąpieliska nad jeziorem i nastąpily kontrole szczelności szamb. Dopiero w ostatnich latach Prądocin jest stopniowo podłączany do sieci kanalizacyjnej.

\subsubsection{CYNKOWNIA W NOWEJ WSI WIELKIEJ}

Firma Metalbark powstała w 1991 r. na terenie osiedla Przylesie w Nowej Wsi Wielkiej. Początkowo była to mała firma wytwarzająca produkty metalowe, a w 1998 r., pośrodku osiedla domów jednorodzinnych, uruchomiono nową halę produkcyjną z magazynem o łącznej powierzchni $2000 \mathrm{~m}^{2}$, wraz z suwnicą o udźwigu $10 \mathrm{t}$ (http:// www.metalbark. $\mathrm{pl} /$ onas). Od tej pory firma zaczęła wykonywać wielkogabarytowe zlecenia. W wyniku tego znacząco zwiększyło się negatywne oddziaływanie firmy na najbliższą okolicę, przyczyniając się do znaczącego obniżenia jakości życia w osiedlu, co spowodowało protesty jego mieszkańców. Władze próbowały lagodzić konflikt, ale jednocześnie nie chciały doprowadzić do upadłości jednego z największych pracodawców w gminie. Ostatecznie firma przeniosła się do Bydgoskiego Parku Przemysłowo-Technologicznego wskutek braku możliwości dalszego rozwoju przedsiębiorstwa $\mathrm{w}$ dotychczasowej lokalizacji. 


\subsubsection{KOPALNIA PIASKU W KOBYLARNI}

W 2010 r. na terenie Łąk Łabiszyńskich powstała kopalnia piasku i żwiru. Przedsiębiorstwo znajduje się $\mathrm{w}$ sąsiedniej gminie Łabiszyn, ale na działce bezpośrednio graniczącej z gminą Nowa Wieś Wielka. Wskutek eksploatacji złoża zaistniała potrzeba transportu urobku. Aby dotrzeć do drogi wojewódzkiej nr 254, ciężarówki przejeżdżały przez Olimpin Wieś, bezpośrednio przy nowo powstałych zabudowaniach. W związku ze wzmożonym ruchem pojazdów mieszkańcy pobliskich posesji zaczęli odczuwać uciążliwość zwiększonego hałasu i zapylenia powietrza. Lokalna społeczność wystosowała protest do władz gminy Nowa Wieś Wielka i zażądała zmiany trasy przejazdu ciężarówek. Argumentowano to faktem, że pojazdy, które niszczą drogi, należą do firmy odprowadzającej podatki w gminie Łabiszyn, nie narażając jej jednocześnie na koszty związane z naprawą dróg.

Pojawił się pomysł, aby ciężarówki zaczęły jeździć droga przez Frydrychowo w gminie Łabiszyn. Trasa ta wprawdzie prowadzi przez niezamieszkane tereny łąkowe, ale jest znacznie dłuższa. Władze Kopalni Torfu i Kruszywa (KTK) Łabiszyn nie wyraziły zgody na poruszanie się zaproponowaną trasą. Po kolejnych protestach i konsultacjach znaleziono alternatywne rozwiązanie. Przedsiębiorstwo zadeklarowało utwardzenie innej drogi, która dotąd była polną, przechodzącą w leśny dukt. Dzięki temu ciężarówki nie nadrabiałyby drogi i nie jeździły bezpośrednio pod oknami mieszkańców.

Wydawało się, że to rozwiązanie zakończy konflikt, ale po otwarciu nowej drogi pojawily się protesty osób z nowych domów w Kobylarni, mimo że pojazdy poruszają się $150 \mathrm{~m}$ od najbliższych zabudowań. (Warto zauważyć, że największe minimalne odległości zabudowań od drogi według norm $\mathrm{w}$ polskim prawie wynoszą $50 \mathrm{~m}$ dla autostrady). Rozwiązanie korzystne dla mieszkańców Olimpina Wsi okazało się nie do zaakceptowania przez mieszkańców Kobylarni. Są oni niezadowoleni z ciągłego hałasu i zaburzenia dotychczasowego sielankowego krajobrazu.

\subsection{POLITYKA WŁADZ GMINY PODDANEJ PRESJI URBANIZACYJNEJ}

W art. 7 pkt 1 Ustawy o samorządzie gminnym, $\mathrm{w}$ ramach zadań własnych gminy na pierwszym miejscu wyszczególniono zadania związane $\mathrm{z}$ ładem przestrzennym, co oznacza, że polityka władz gminy wywiera istotny wpływ na kształtowa- nie lokalnej struktury funkcjonalno-przestrzennej (Kowalewski, Makowski, Śleszyński, 2018). 5 października 2010 r. Rada Gminy Nowa Wieś Wielka uchwaliła trzecią edycję dokumentu „Studium uwarunkowań i kierunków zagospodarowania przestrzennego gminy Nowa Wieś Wielka". Studium jest opracowaniem planistycznym wiążącym dla władz gminy przy opracowywaniu miejscowych planów zagospodarowania przestrzennego. Jednak studium to nie jest dokumentem prawa miejscowego i nie może być podstawą do wydawania decyzji o warunkach zabudowy. Fakt ten ma istotne znaczenie dla inwestorów na terenach znajdujących się poza planami miejscowymi, gdyż nie mogą oni uzyskać potrzebnych informacji odnoszących się do przyszłego wykorzystania sąsiednich gruntów. Na terenach niezabudowanych, graniczących $\mathrm{z}$ zabudową mieszkaniową oraz przemysłową, w świetle obowiązującego prawa można uzyskać warunki zabudowy zarówno dla lokowania jednej, jak i drugiej funkcji (Ładziński, 2011). Wskutek tego zanika strefa buforowa oddzielająca obszary będące w naturalnym konflikcie interesów. W przywołanym studium określono funkcje przewidziane dla określonych części gminy, jednak nie są one konsekwentnie realizowane. Gmina nie jest bowiem w całości pokryta miejscowymi planami zagospodarowania przestrzennego, a istniejące plany są często niskiej jakości, co jest niestety charakterystyczne dla większości gmin w Polsce (Śleszyński, Deręgowska, Kubiak, Sadura, Zielińska, 2018).

W 2008 r. w gminie Nowa Wieś Wielka obowiązywało 29 miejscowych planów zagospodarowania przestrzennego dotyczących łącznego areału 888 ha, co stanowi 5,98\% powierzchni gminy (nie biorąc pod uwagę obszarów lasów, łąk i pastwisk 30,91\%). Z szacunków Referatu Gospodarki Gruntami i Zagospodarowania Przestrzennego wynika, że na obszarach objętych planami zagospodarowania przestrzennego istnieje możliwość wydzielenia 3552 działek; zagospodarowanych było jedynie $1673 \mathrm{z}$ nich. Wobec powyższego $\mathrm{w}$ obowiązujących planach istniała potencjalna możliwość zagospodarowania 1879 nieruchomości. W roku 2008 na terenach objętych miejscowymi planami zagospodarowania przestrzennego istniały rezerwy pozwalające na przyrost zabudowy o około $112 \%$. Na analizowanym obszarze do końca 2010 r. zostało zagospodarowanych 37 nowych działek, co sprawiło, że stopień zainwestowania działek zwiększył się z 47 do $48 \%$. Jednak między 2008 i 2010 r. uchwalono kolejne dwa plany, obejmujące razem powierzchnię 132 ha, na których potencjalnie może się zmieścić 118 działek, 
ale zainwestowanych jest zaledwie 30 . Wskutek tego we wszystkich obowiązujących miejscowych planach zagospodarowania przestrzennego $\mathrm{w} 2011 \mathrm{r}$. było zainwestowanych zaledwie $47,4 \%$ działek. Oznacza to, że na terenie gminy ma miejsce duża nadpodaż gruntów budowlanych, która sprzyja nieefektywnemu rozpraszaniu zabudowy (Śleszyński, Deręgowska, Kubiak, Sadura, Sielińska, 2018), przyczyniającemu się do kosztownego „rozlewania się” miast (Karwińska, Kudłacz, Węcławowicz, 2017).

Obszary objęte miejscowymi planami zagospodarowania przestrzennego posiadają różny stopień wyposażenia $\mathrm{w}$ podstawowe sieci infrastruktury technicznej. Przyczyną tego stanu rzeczy jest również nieracjonalne rozpraszanie się zabudowy, które nadmiernie zwiększa potrzeby infrastrukturalne (Sudra, 2016; Śleszyński, Sudra, 2019). W efekcie powstaje permanentna luka inwestycyjna, której lokalne władze nie są w stanie zaspokoić ze względów finansowych. W 2008 r. tylko siedem planów, obejmujących łączną powierzchnię 127 ha, zawierało tereny wyposażone zarówno $\mathrm{w}$ sieć wodociągową, jak i kanalizacyjną. Znajdują się one w dwóch głównych zespołach miejscowości (Brzoza - Olimpin i Nowa Wieś Wielka - Dziemionna). Zlokalizowane są tam 652 działki, z których 406 było zainwestowanych. W ciągu kolejnych trzech lat przybyło 10 nowo zabudowanych działek, co sprawiło, że stopień ich zainwestowania na terenach wyposażonych w obie sieci zwiększył się z 62 do $64 \%$. Są to zatem obszary najintensywniej zagospodarowane na terenie gminy, na których powoli zaczyna brakować rezerw terenowych pod dalszy rozwój zabudowy. Nieruchomości znajdujące się na obszarze kolejnych dziewięciu planów mogą zostać przyłączone tylko do sieci wodociągowej. Dotyczy to nowych osiedli w Nowej Wsi Wielkiej i Brzozie oraz miejscowości: Dziemionna, Tarkowo Dolne i Kobylarnia. Stopień wykorzystania działek wynosi tam zaledwie 31\%. Oznacza to, że byłoby racjonalne preferowanie właśnie tych terenów do rozwoju mieszkalnictwa. Jest to bardziej rozsądne niż uchwalanie miejscowych planów zagospodarowania przestrzennego na obszarach całkowicie pozbawionych infrastruktury technicznej. Do 2011 r. powstało 15 stosownych uchwal, a kolejne są w trakcie realizacji. Aż osiem $\mathrm{z}$ nich przygotowano dla Prądocina. W 2011 r. była to największa miejscowość bez dostępu zarówno do sieci kanalizacyjnej, jak i wodociągowej. Oprócz planów dla Prądocina tworzy się je także dla bardziej peryferyjnie położonych miejscowości w celu uatrakcyjnienia tamtejszych gruntów dla mieszkalnictwa.
W Polsce istnieje możliwość realizacji inwestycji budowlanych także na obszarach nieobjętych miejscowymi planami zagospodarowania przestrzennego w oparciu o warunki zabudowy i zagospodarowania terenu. Taką ewentualność dopuszczają zapisy zawarte w Ustawie o planowaniu i zagospodarowaniu przestrzennym z 27 marca $2003 \mathrm{r}$. W intencji twórców ustawy praktyka wydawania warunków zabudowy miała dotyczyć tylko wyjątkowych sytuacji. Niestety nieprecyzyjność przepisów pozwala na nadużywanie tego instrumentu prawnego przyczyniając się do zwiększania skali procesu urban sprawl na obszarach, które powinny być objęte ciszą urbanizacyjną (Kowalewski, Markowski, Śleszyński, 2018). Warto zauważyć, że w latach 2008-2010 wydano 190 decyzji o warunkach zabudowy, a zostało zainwestowanych tylko 37 dotąd niezabudowanych działek $\mathrm{z}$ miejscowych planów zagospodarowania przestrzennego (tab. 3).

Tab. 3. Liczba wydanych decyzji o warunkach zabudowy i zagospodarowania terenu w gminie Nowa Wieś Wielka

\begin{tabular}{|l|c|c|}
\hline \multirow{2}{*}{ Rok } & \multicolumn{2}{|c|}{ Liczba wydanych decyzji } \\
\cline { 2 - 3 } & $\begin{array}{c}\text { o warunkach } \\
\text { zabudowy }\end{array}$ & $\begin{array}{c}\text { lokalizacji celu } \\
\text { publicznego }\end{array}$ \\
\hline 2006 & 60 & 4 \\
\hline 2007 & 66 & 8 \\
\hline 2008 & 66 & 23 \\
\hline 2009 & 62 & 15 \\
\hline 2010 & 62 & 7 \\
\hline Razem & 316 & 57 \\
\hline
\end{tabular}

Źródło: Ładziński (2011).

Przykładami dysharmonii w otoczeniu jest lokalizowanie na terenach łąk, śródleśnych enklaw, terenach oddalonych od zabudowy wsi nowych budynków mieszkalnych wykonywanych w ramach zabudowy zagrodowej lub też szeroko pojętej zasady tzw. dobrego sąsiedztwa (Ładziński, 2011). W obecnej sytuacji prawnej jedynym narzędziem ograniczającym to zjawisko jest opracowanie planów miejscowych, w których teren przeznacza się do produkcji rolnej i leśnej bez możliwości lokalizowania wszelkich obiektów budowlanych. Takie rozwiązanie, z uwagi na niską bonitację gleb, faktycznie nie przysłuży się rozwojowi rolnictwa, lecz uchroni dotychczasowe otwarte przestrzenie, kompleksy łąk, zachowa wartości krajobrazowe. Ponadto uchroniłoby to budżet gminy przed powstaniem dodatkowych zobowiązań z tytułu wykupu i budowy od podstaw dróg dojazdowych oraz rozwoju nierentownych sieci infrastruktury technicznej. Jednak osobliwa sytuacja planistyczna w Polsce przy- 
czynia się do spekulacji gruntami, roszczeniowej postawy właścicieli gruntów oraz dowolności w ich zagospodarowaniu, która powoduje, że w praktyce prawo własności nieruchomości nie jest traktowane odrębnie z prawem do zabudowy (Krajewska, 2017).

Próbą wprowadzenia ograniczenia zabudowywania terenów otwartych było utworzenie w $2000 \mathrm{r}$. Obszaru Chronionego Krajobrazu Łąki Nadnoteckie. Już w 2003 r., uchwałą Rady Gminy Nowa Wieś Wielka, pomniejszono go o 36 ha do obecnej powierzchni 1165 ha. Na terenie wyjętym spod ochrony dokonano parcelacji gruntów i powstało tam kilka zabudowań, które klinem wcinają się w obszar chronionego krajobrazu obowiązujący w obecnym kształcie. Aktualne Studium przedstawia ten rejon jako potencjalnie rozwojowy dla mieszkalnictwa. OChK Łąki Nadnoteckie skupia się na ochronie krajobrazu niezabudowanych łąk, a nie na zakazie ich zabudowywania. Prowadzi to do paradoksalnej sytuacji, w której krajobraz nie jest skutecznie chroniony. Od czasu jego powołania już zdążyły powstać tam zabudowania. $W$ celu ochrony wartości przyrodniczych i krajobrazowych rezerwatu przyrody Dziki Ostrów w 2010 r. podjęto uchwałę o wyznaczeniu wokół niego strefy zakazu zabudowy. Do tej pory są respektowane jej postanowienia, choć tuż przed powołaniem tej strefy, zaraz przy granicy rezerwatu, powstała nowe budynki. Na tym fragmencie zakaz nie obowiązuje. Okazuje się, że najlepiej chronionymi przed zabudową terenami są obszary leśne. Chronią je zapisy Ustawy o gruntach rolnych i leśnych. W praktyce jest bardzo trudno zmienić użytkowanie takich obszarów, głównie kiedy nie dotyczy to inwestycji celu publicznego. Wówczas takie decyzje zapadają na poziomie Ministra ds. Środowiska. Nawet jeśli uzyska się taką zgodę, wiąże się ona z potrzebą przeprowadzenia kompensacji środowiskowej. Ta sama ustawa reguluje również kwestie związane z ochroną gruntów rolnych, choć ominięcie jej przepisów jest dużo łatwiejsze niż dotyczących lasów. Nawet na glebach chronionych klas I-IIIa jest możliwa zabudowa, jeśli działka jest wystarczającej wielkości.

\section{PODSUMOWANIE}

$\mathrm{Z}$ analizy danych zawartych $\mathrm{w}$ przedstawionym artykule $w$ tab. 1-3 i na rys. 3, 4, 6 i 7 wynika, że w latach 90. XX w. i na początku obecnego stulecia największa dynamika przyrostu liczby ludności była notowana w głównych miejscowościach, czyli
Nowej Wsi Wielkiej z Dziemionną oraz Brzozie z Olimpinem. W ostatnich latach liczba mieszkańców zwiększała się znacząco także w pozostałych miejscowościach położonych wzdłuż głównych szlaków komunikacyjnych, takich jak Kobylarnia, Prądocin czy Tarkowo Dolne.

Pomimo istotnych inwestycji w rozwój sieci kanalizacyjnej i wodociągowej $\mathrm{w}$ gminie Nowa Wieś Wielka w ostatnich latach występują znaczne opóźnienia $\mathrm{w}$ rozwoju infrastruktury towarzyszącej względem sieci osadniczej. Jest to spowodowane zbyt dużą podażą gruntów pod funkcję mieszkaniową, przewidzianą $\mathrm{w}$ "Studium uwarunkowań i kierunków zagospodarowania przestrzennego gminy Nowa Wieś Wielka". Ponadto niekorzystnemu rozproszeniu zabudowy sprzyja możliwość uzyskania decyzji o warunkach zabudowy na terenach przeznaczonych pod inne funkcje. Na obszarze gminy Nowa Wieś Wielka występują także procesy suburbanizacji, polegającej na nadaniu miejskiego charakteru niektórym miejscowościom. Takimi przykładami są Nowa Wieś Wielka i Brzoza, które pełnią coraz więcej funkcji miejskich oraz morfologicznie coraz bardziej się do miast upodabniają. Jednocześnie widoczne są też procesy urban sprawl, które mają miejsce w pozostałej części gminy. Powstaje tam struktura funkcjonalno-przestrzenna składająca się z elementów utożsamianych $\mathrm{z}$ miejskim trybem życia. Jednak ta nowa forma osadnicza nie jest ani miastem ani wsią. Zaburzenie zasad zrównoważonego rozwoju i ładu przestrzennego występuje tam we wszelkich aspektach życia: ekonomicznym, społecznym i środowiskowym.

W początkowej fazie zabudowywania podmiejskich terenów otwartych usatysfakcjonowani są zarówno nowi mieszkańcy, jak i rolnicy czy władze. Rolnicy mają możliwość uzyskania dochodów ze sprzedaży ziemi. Nowi mieszkańcy realizują swoje marzenia o własnym domu na przedmieściach, odczuwając korzyści płynące $\mathrm{z}$ mieszkania na odludziu. Natomiast lokalne władze są usatysfakcjonowane tym, że wyszły naprzeciw oczekiwaniom mieszkańców, podejmując tylko doraźne działania dotyczące ladu przestrzennego, przy braku strategicznej wizji rozwoju funkcjonalno-przestrzennego gminy.

Niestety świadomość władz i mieszkańców na temat negatywnych skutków urban sprawl jest bardzo niewielka. Z czasem sielankowa atmosfera ustąpiła miejsca licznym problemom związanym $z$ nieumiejętnym zagospodarowaniem przestrzeni, czego przykładami są konflikty związane $\mathrm{z}$ działalnością firm KTK Łabiszyn i Metalbark lub eutrofizacja Jezio- 
ra Jezuickiego. Wzrasta uzależnienie ludności od korzystania z samochodu, powodując zmniejszenie przepustowości głównych ciągów komunikacyjnych i zwiększenie kosztów transportu. Skutkiem urban sprawl jest także obniżenie wartości przyrodniczych, brak ładu przestrzennego oraz nieefektywne wykorzystanie terenu, które utrudnia życie mieszkańcom.

\section{BIBLIOGRAFIA}

Falkowski, J., Ilieva, M., Józefowicz, I., Rabant, H. (2015). Bydgoszcz i jej otoczenie na poczatku XXI wieku. Wybrane zagadnienia. Bydgoszcz: Wyd. Uniwersytetu Kazimierza Wielkiego.

Głębocki, B., Perdał, R. (2013). Rynek nieruchomości gruntowych w powiecie bydgoskim w latach 2007-2010. Rozwój Regionalny i Polityka Regionalna, 22, s. 57-75.

Gotowski, R. (2007). Jednorodzinne budownictwo mieszkaniowe w latach 1988-2002 jako przejaw procesów urbanizacyjnych na obszarze powiatu bydgoskiego. Promotio Geographica Bydgostiensia, 3, s. 55-68.

Jaroszewska-Brudnicka, R. (2009). Przemiany społeczno-przestrzenne obszarów wiejskich w przestrzeni metropolitalnej Bydgoszczy i Torunia. W: W. Maik (red.), Aglomeracje miejskie w Polsce na przetomie XX $i$ XXI w. Problemy rozwoju, przeksztatcenia strukturalne i funkcjonalne (s. 315-331). Bydgoszcz: Wyd. Uczelniane Wyższej Szkoły Gospodarki.

Kajdanek, K. (2012). Suburbanizacja po polsku. Kraków: Zakład Wydawniczy Nomos.

Karwińska, A., Kudłacz, M., Węcławowicz, G. (2017). Dysfunkcje i eufunkcje amorficznego rozlewania miast w Polsce - perspektywa badawcza. Studia KPZK PAN, 174, s. 94-102.

Kowalczyk, A. (2002). Przekształcenia środowiska przyrodniczego strefy okołomiejskiej wskutek rozwoju miasta na przykładzie Bydgoszczy. W: K. German, J. Balon (red.), Przemiany środowiska przyrodniczego Polski a jego funkcjonowanie. Problemy Ekologii Krajobrazu, 10, s. 149-157. Kraków: IGiGP.

Kowalewski, A., Markowski, T., Śleszyński, P. (red.) (2018). Koszty chaosu przestrzennego, Studia KPZK PAN, 182.

Krajewska, M. (2011). Kształtowanie się wartości gruntów w strefie podmiejskiej miasta Bydgoszczy. Zeszyty Naukowe Uniwersytetu Ekonomicznego w Poznaniu, 192, s. 70-80.
Krajewska, M. (2017). Wartość gruntu w procesie przekształcania przestrzeni. Bydgoszcz: Uniwersytet Technologiczno-Przyrodniczy.

Lisowski, A., Grochowski, M. (2009). Procesy suburbanizacji. Uwarunkowania, formy, konsekwencje. Biuletyn KPZK, 240 (l), s. $216-280$

Ładziński, R. (2011). Analiza zmian w zagospodarowaniu przestrzennym gminy 2006-2010. Nowa Wieś Wielka: Referat Gospodarki Gruntami i Zagospodarowania Przestrzennego.

Maik, W. (2010). Bydgosko-Toruński Obszar Metropolitalny jako czynnik rozwoju i integracji województwa kujawsko-pomorskiego. W: S. Ciok, P. Migoń (red.), Przeksztatcenia struktur regionalnych. Aspekty społeczne, ekonomiczne i przyrodnicze (s. 65-74). Wrocław: Instytut Geografii i Rozwoju Regionalnego Uniwersytetu Wrocławskiego.

Mantey, D. (2011). Żywiotowość lokalizacji osiedli mieszkaniowych na terenach wiejskich obszaru metropolitalnego Warszawy. Warszawa: Uniwersytet Warszawski, Wydział Geografii i Studiów Regionalnych.

Oueslati, W., Alvanides, S., Garrod, G. (2015). Determinants of urban sprawl in European cities. Urban Studies, 52, 9, s. 15941614.

Studium uwarunkowań i kierunków zagospodarowania przestrzennego gminy Nowa Wieś Wielka (2006).

Sudra, P. (2016). Zastosowanie wskaźników koncentracji przestrzennej w badaniu procesów urban sprawl. Przegląd Geograficzny, 88, 2, s. 247-272.

Szymańska, D., Hołowiecka, B. (2000). Ruch wędrówkowy ludności i jego zasięg oddziaływania na przykładzie miasta Bydgoszczy i Torunia. W: D. Szymańska (red.), Procesy i formy ruchliwości przestrzennej ludności w okresie przemian ustrojowych (s. 217-226). Torun: Wyd. Uniwersytetu Mikołaja Kopernika.

Śleszyński, P. (2013). Delimitacja Miejskich Obszarów Funkcjonalnych stolic województw. Przegląd Geograficzny, 85, 2, s. 173-197.

Śleszyński, P., Deręgowska, A., Kubiak, Ł., Sudra, P., Zielińska, B. (2018). Analiza stanu i uwarunkowań prac planistycznych w gminach w 2017 roku. Warszawa: Instytut Geografii i Przestrzennego Zagospodarowania PAN.

Śleszyński, P., Sudra, P. (2019). Zastosowanie metody minimalnego drzewa rozpinającego (najkrótszego dendrytu) w ocenie efektywności i spójności sieci osadniczej województwa mazowieckiego. Przeglad Geograficzny, 91, 2, s. 61-80.

Zborowski, A., Raźniak, P. (2013). Suburbanizacja rezydencjalna w Polsce: ocena procesu. Studia Miejskie, 9, s. 37-50.

http:/ / www.metalbark.pl/onas. 